\title{
Urgensi Psikologi Massa dalam Perencanaan Dakwah di Youtube
}

\section{(The Urgency of Mass Psychology in Dakwah Planning on Youtube)}

\author{
Lailatur Rofidah \\ Komunikasi dan Penyiaran Islam, Universitas Islam Negeri Sunan Ampel Surabaya, Indonesia \\ email: lailaturrofidah@gmail.com
}

First received:

5 July 2021
Revised:
15 September 2021

Final Accepted:

18 October 2021

\begin{abstract}
This study to explain how the urgency of mass psychology of dakwah plan on Youtube. Descriptive qualitative method is used to this study. The data is collected by library research technics, from article, books, website and online news. And the data analyzing used mass psychology approach. The result of this study shows that dakwah through Youtube make netizen as dakwah partners. To reach the purpose of dakwah. As the preacher have to arrange dakwah plan. The urgency of mass phycology in the dakwah plan is found in audience analysis, where audience analysis can be analyzed in terms of psychographics. Mass psychology states that individual actions or behavior can be merged if they are joined in mass which forms collective behavior. The collective behavior of netizen can be seen from the trending tab on Youtube, where videos that get a lot of views and currently trending, so the videos will be displayed on the trending topic homepage and will influence netizen to wacth. In conclusion, dakwah plan needs to be done by preacher before doing dakwah on Youtube, as the purpose of dakwah is to be able to onfluence, and change the behavior of dakwah partners to comply with religious guidance. So the preacher have to be able to understanding the natizen's character, as well as the right medium, so the dakwah message can be found and understood easily.
\end{abstract}

Keywords : Mass Psychology; Dakwah Plan; Youtube; Netizen.

ABSTRAK
Penelitian ini bertujuan untuk melihat bagaimana urgensi psikologi massa dalam perencanaan dakwah di Youtube. Penelitian ini menggunakan metode kualitatif deskriptif, dengan kajian pustaka sebagai teknik pengumpulan data. Data didapatkan dari artikel, buku, website, dan berita online. kemudian data dianalisa menggunakan pendekatan psikologi massa. Hasil dari penelitian ini menunujukkan bahwa, berdakwah melalui Youtube menjadikan netizen sebagai mitra dakwah, untuk mencapai tujuan dakwah, pendakwah harus menyusun perencanaan dakwah. Dalam perencanaan dakwah urgensi psikologi massa terdapat pada analisis khalayak, dimana analisis khalayak dapat dianalisa dari segi psikografis. Psikologi massa menyebutkan bahwa tindakan atau perilaku individu dapat melebur jika ia tergabung dalam massa yang kemudian membentuk perilaku kolektif. Perilaku kolektif netizen dapat dilihat dari tab trending di Youtube, dimana video yang mendapat banyak penonton dan sedang tren saat itu, akan ditampilkan di beranda trending topik dan akan mempengaruhi netizen untuk ikut menonton. Kesimpulannya perencanaan dakwah perlu dilakukan pendakwah sebelum masuk ke lapangan. Sebagaimana tujuan dakwah untuk dapat mempengaruhi, dan mengubah perilaku mitra dakwah agar sesuai dengan tuntunan agama. Maka seorang pendakwah harus dapat memahami karakter netizen, serta media yang tepat untuk berdakwah sehingga mudah ditemui dan dipahami.

Kata kunci : Psikologi Massa; Perencanaan Dakwah; Youtube; Netizen.

\section{PENDAHULUAN}

Kemajuan teknologi dan internet, menjadi jantung utama peradaban digital saat ini, hal ini mampu menggeser ruang interaksi masyarakat yang kini sudah berbasis digital salah satunya melalui social media. Social media menjadi wahana interaksi masyarakat di dunia maya, dimana mereka sudah tidak dibatasi lagi oleh ruang dan waktu, serta dengan siapapun. Pergeseran 
ruang interaksi tidak menyurutkan semangat pendakwah untuk terus menunaikan kewajiban dalam menyampaikan kebaikan. Di awal tahun 2021 pengguna social media di Indonesia mencapai 202,6 juta dan YouTube menjadi salah satu sosial yang paling banyak digunakan mencapai 94\% dari populasi, penggunanya dari rentan usia 16 s.d 64 tahun (Dahono, 2021). Media sosial yang saat ini banyak digunakan oleh pendakwah untuk menyampaikan pesan dakwahnya secara mudah kepada khalayak khsusnya di Youtube. Mulai banyak pendakwah membuat channel Youtube agar dapat lebih dekat dengan mand'u, karena dalam instagram berdakwah dapat dilakukan melalui video, live streaming, dan juga audio. Instagram dapat digunakan sebagai salah dsatu media dakwah di media sosial. Pengguna media sosial tentunya tidak lepas dari generasi millennial, dimana mereka yang dikenal sebagai generasi yang terdampak langsung oleh perkembangan internet. Dari jumlah populasi masyarakat Indonesia yakni 279,9 juta jiwa, 61,8\% merupakan pengguna aktif media sosial, dan didominasi oleh warga dengan rentang usia 25-34, kemudian kelompok usia 18-24 (Haryanto, 2021). Dilihat dari segi usia pengguna media sosial, dapat menjadi referensi bagi pendakwah dalam proses perencanaan dakwah.

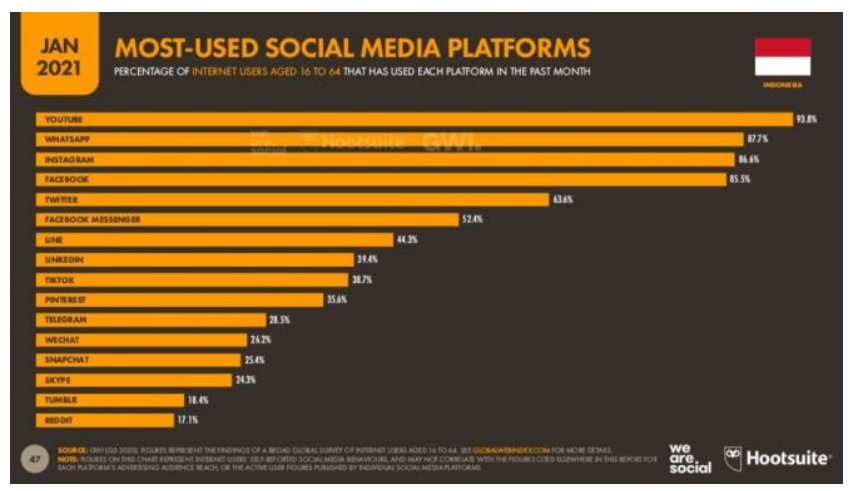

Sumber: Kompas.com

Dari gambar diatas dapat diketahui, bahwa Youtube menjadi salah satu media sosial yang banyak diakses oleh netizen. Dengan ini Youtube dapat menjadi media yang efektif untuk melakukan dakwah. Dalam Youtube sendiri menyediakan mekanisme interaksi sosial untuk melihat pendapat pengguna dan pandangan pengguna tentang video dengan cara voting, rating, favorit, share, subscribe, dan komentar (Vito, 2018). Interaksi sosial ini dapat terjadi antara pendakwah dengan mad'u, serta antaramad'u dengan mad'u. Dengan tejadinya interaksi sosial tersebut, dapat menjadi bahan bagi pendakwah untuk melihat karakteristik mad'u-nya.

Pada dasarnya dakwah sendiri memiliki tujuan untuk dapat mempengaruhi hingga mengubah tingkah laku manusia dari sikap dan perilaku negatif ke tingkah laku positif (Hidayat). Berdakwah melalui sosial media akan dapat didengarkan oleh banyak golongan, tidak hanya orang muslim sendiri namun juga dari kalangan non-muslim, dari kalangan pemuda atau millennial, dan juga kalangan tua yang dikenal sebagai netizen. Media sosial memberikan pengaruh besar dalam menyebarkan pesan dakwah hingga sampai pada khalayak. Oleh karena itu tentu pesan yang terkandung dalam dakwah tersebut memberikan efek pada mad'u. Dari sini mad'u atau sasaran dakwah di media sosial Youtube yakni netizen atau dikenal sebagai warganet atau warga internet. Seorang pendakwah tentu dihadapkan dengan berbagai respon, kepribadian, pemikiran dan pengalaman netizen sebagai mad'u (Fabriar, 2019). Oleh karena itu penting bagi seorang pendakwah untuk dapat memahami mad'u nya, khususnya para netizen untuk dapat mencapai tujuan dakwah itu sendiri. Sebagaimana tujuan dakwah menurut Mansyur Amin, tujuan dakwah dibagi menjadi dua, yakni: tujuan dakwah dari segi subjeknya terbagi menjadi tujuan dakwah perorangan, untuk keluarga, untuk masyarakat, dan seluruh umat; dan tujuan dakwah dari segi materinya, terbagi dalam tujuan akidah, tujuan hukun dan 
akhlak (Ikhsan). Dilihat dari media dakwah yang digunakan pendakwah yang menggunakan media sosial tujuan dakwah dari segi subjeknya lebih pada tujuan untuk seluruh umat, dikarenakan media sosial dapat diakses oleh siapa saja. Sedangkan dari segi materinya, tujuan dakwah melalui media sosial dapat mencakup ketiga tujuan tersebut, karena dalam media sosial siapapun pendakwahnya membawa berbagai macam materi, dan netizen dapat dengan mudah mencari materi mana yang materi dakwah seperti apa yang mereka butuhkan. keberagaman dan perbedaan kebutuhan materi dakwah netizen di media sosial menjadi tantangan tersendiri bagi seorang pendakwah.

Untuk mencapai tujuan dakwah di media sosial, perlu adanya perencanaan sebelum melakukan dakwah. Hal ini berkaitan dengan perencanaan komunikasi dalam dakwah. Perencanaan komunikasi sendiri merupakan dokumen tertulis yang menggambarkan tentang apa yang harus dilakukan dalam komunikasi yang berkaitan dengan pencapaian tujuan, dengan cara apa agar tujuan tersebut tercapai, dan kepada siapa program tersebut ditujukan, dengan peralatan apa, dan dalam jangka waktu berapa lama, kemudian bagaimana evaluasi hasil dari program tersebut (Wijaya, 2015). Dengan adanya perencanaan komunikasi sebelum melaksanakan dakwah, diharapkan agar pesan-pesan dakwah dapat diterima dan dipahami oleh mad'u. Disini peran psikologi juga sangat dibutuhkan guna melihat keaadaan mad'u, khususnya netizen, sebab dalam psikologi sendiri juga memberikan tips dan trik bagaimana cara memecahkan masalah kemanusian yang dialami individu atau kelompok.

Psikologi dalam masyarakat modern kedudukan dan perannya dapat dikatakan sebagai sarana efektif dalam menentukan berhasil tidaknya tujuan dakwah itu sendiri, baik secara perorangan maupun kelompok (Fabriar, 2019). Sebagai seorang pendakwah perlu untuk mempelajari proses psikologi mad'u sebagai metode dakwah di media social. Hal ini sebagai acuan untuk menelaah tingkah laku mad'u dan sebagai bahan evaluasi dalam proses dakwah. Proses dakwah di media sosial khususnya Youtube terdapat proses interaksi antara netizen dengan pendakwah atau antar netizen sendiri melalui kolom komentar, atau Tanya jawab langsung melalui live streaming. Netizen saat ini dapat kita ketahui meraka memiliki kepribadian yang berbeda dari kehidupan sosial dan kehidupan nyata. Dakwah yang dilakukan di media sosial diharapkan mampu merubah pemikiran dan tingkah laku netizen.Adanya proses interaksi ini, psikologi massa memiliki peran tersendiri untuk melihat sikap, kognisi, dan karakter netizen sebagai kelompok massa di media sosial.

Peran psikologi sangat dibutuhkan sebagai bahan pendakwah sebelum masuk lapangan. Psikologi menjadi salah satu kajian ilmu yang memperlajari menganai kejiwaan manusia. Psikologi berasal dari bahasa Yunani psyche yang artinya nafas atau jiwa, dan logos yang berarti ilmu (Daulay, 2014). Dengan menggunakan ilmu psikologi dalam merencanakan dakwah media sosial akan membantu pendakwah agar pesan-pesan keagamaan dapat mempengaruhi mad'u. Psikologi sebagai ilmu mengenai aktivitas individual digunakan secara luas, tidak hanya mencakup aktivitas motorik, tetapi juga mencakup aktivitas kognitif dan emosional (Daulay, 2014). Dengan memperhatikan psikologi netizen pendakwah akan lebih mudah untuk mempersiapkan materi dakwah dan strategi dakwah agar mencapai tujuan dakwah.

Penelitian ini bertujuan untuk melihat bagaimana urgensi psikologi massa dalam perencanaan dakwah di media sosial Youtube. Dengan menggunakan pendekatan khalayak dalam perencanaan komunikasi, serta menggunakan pendekatan psikologi massa sebagai kacamata penelitian.

\section{METODE PENELITIAN}

Penelitian ini menggunakan metode penelitian kualitatif yang menghasilkan data deskritif. Teknik pengumpulan data digunakan adalah kajian pustaka yang berupa artikel, buku, dan berita online. Kemudian data akan dianalisa menggunakan teknik analisis data dari Miles dan Huberman. Teknik analisis yang dilakukan, yakni: pengumpulan data, reduksi data, penyajian 
data, dan menarik kesimpulan. Penelitian ini juga menggunakan pendekatan psikologi massa sebagai kacamata penelitian.

Selanjutnya, metode penelitian dengan menggunakan pendekatan kualitatif mencakup beberapa hal terkait sebagai berikut penjelasan tentang bentuk pendekatan kualitatif yang diambil; subjek penelitian; metode dan alat pengumpulan data; validasi dan transferabilitas; dan metode analisis data. Metode ini ditulis secara deskriptif dalam bentuk paragraf tanpa disertai dengan nomor atau poin.

\section{HASIL PENELITIAN DAN PEMBAHASAN}

\section{Netizen sebagai Mitra Dakwah dalam Dakwah di Media Sosial Youtube}

Aktifitas dakwah merupakan kewajiban bagi seorang muslim, khususnya saling mengingatkan dalam kebaikan, karena dakwah bisa dilakukan oleh setiap muslim. Secara etimologis dakwah berasal dari bahasa Arab berupa masdar (kata benda)_dari kata da'a yad'u yang artinya panggilan, seruan atau ajakan (Fabriar, 2019). Dari makna dakwah tersebut, setiap muslim memiliki kewajiban untuk saling mengajak sesamanya dalam kebaikan. Menurut Abu Bakar Zakaria menyebutkan dakwah merupakan usaha para ulama dan orang-orang yang memiliki pengetahuan agama islam untuk memberikan pengajaran kepada khalayak umum sesuai dengan kemampuan yang dimiliki tentang hal-hal yang mereka butuhkan dalam urusan dunia dan agama (Aziz, 2017). Sedangkan dalam buku yang ditulis Kustandi Suhandang menyebutkan bahwa dakwah islamiyah merupakan suatu kegiatan mengkomunikasikan ajaran Allah yang terkandung dalam Al-Qur'an dan as-Sunnah (Suhandang, 2013). Dakwah menjadi salah satu aktifitas yang memang diwajibkan bagi setiap muslim yang mana harus saling mengingatkan akan kebaikan. Sebagaimana dalam surah az Zariyat ayat 55, yang artinya "Dan tetaplah memberi peringatan, karena sesungguhnya peringatan itu bermanfaat bagi orangorang yang beriman". Tafsir Kemenag Indonesia menyebutkan bahwa Nabi Muhammad diperintahkan untuk tetap memberikan peringatan dan nasihat. Dalam dakwah melibatkan beberapa unsur, terdiri dari da'i (subjek dakwah), mad'u (objek dakwah), materi, metode, media, dan tujuan, selain itu perencanaan juga dimasukkan dalam unsur dakwah (Fabriar, 2019).

Secara operasional, dakwah merupakan suatu aktifitas yang mana mengajak manusia pada jalan kebaikan berdasarkan pada al-Qur'an dan Hadist, hal ini juga sebagai bagian dari tujuan dakwah itu sendiri. Dakwah juga menjadi bentuk dari peristiwa komunikasi, dan terdapat interaksi sosial dalam proses dakwah, sehingga dapat menimbulkan berbagai peristiwa di masyarakat (Fabriar, 2019). Oleh karena itu pentingnya bagi seorang da'i untuk memahami karakter dari objek dakwah atau mad'u, serta pentingnya tingkat keilmuan seorang pendakwah., sehingga tidak terjadi kesalahpahaman dalam memaknai pesan dakwah. Seorang pendakwah tentunya harus tetap berinovasi agar pesan-pesan dakwah tersampaikan.

Pada era digital saat ini mulai banyak media-media online yang dapat digunakan untuk melanyurkan pesan dakwah. Media dakwah menurut Abdul Kadir Munsyi merupakan alat yang menjadi saluran yang menghubungkan ide dengan umat (Aziz, 2017). Media menjadi salah satu unsur dari dakwah, disisi lain media dakwah selalu berkembang mengikuti zaman. Seperti saat ini yang masuk pada era digital, tidak menjadi halangan bagi pendakwah untuk menyebarkan pesan-pesan keagamaan. Di era digital mulai banyak menggunakan media online, dimana interaksi sosial juga terjadi dalam media online, yang banyak dikenal sebagai media sosial. Youtube menjadi salah satu media sosial yang banyak diakses oleh masyarakat Indonesia, dengan berbagai fitur yang disediakan, Youtube dapat membagikan Video, audio, live streaming, dan trending tab. Dalam Youtube juga terdapat interaksi sosial antara pendakwah dengan objek dakwah atau mad'u melalui fitur komentar, dan subscribe. Saat ini Youtube menjadi media untuk aktifitas keagamaan, tidak hanya sebagai media dakwah tapi juga sebagai media untuk berbagi aktifitas keagamaan yang dibagikan dengan bentuk video. Youtube 
menjadi media dakwah dapat dilakukan dengan cara membuat channel Youtube yang berimuatan pesan-pesan keagamaan. Tidak jarang juga seorang da'i yang juga mulai membuat akun sendiri, sehingga bisa berinteraksi langsung dengan mitra dakwah.

Aktifitas dakwah yang mulai bergeser dari konvensionla menjadi digital, khususnya dengan menggunakan rana media sosial dapat memudahkan siapapun untuk belajar agama. Bahkan hal ini pun memberikan kemudahan bagi pendakwah tanpa perlu mengumpulkan massa untuk berdakwah, tetapi hanya perlu membuat video dan membagikannya di channel youtube. Youtube sudah menjadi bagian dari ruang berinteraksi antara satu dengan yang lain, tanpa ada batas waktu, serta bisa dilakukan dimanapun dan kapanpun (Sulaeman, A. R., Fazri, A., \& Fairus, 2020). Sebagaimana perkembangan media dakwah yang dipengaruhi oleh digitalisasi, juga memberikan pengaruh pada perkembangan objek dakwah atau mad'u. secara terminologi mad'u adalah orang atau kelompok atau jamaah yang sedang menuntut ajaran agama dari seorang da'i, baik mad'u itu jauh atau dekat, muslim atau non muslim, laki-laki atau perempuan (Marwantika, 2019). Sedangkan menurut Ali Aziz menyebut objek dakwah sebagai mitra dakwah, dikarenakan pendakwah diposisikan sebagai kawan berpikir dan bertindak bersama dengan mitra dakwah (Aziz, 2017). Dengan menyebut subjek dawah sebagai mitra dakwah akan dapat menambah kedekatan antara pendakwah dengan khalayak. Mitra dakwah di era digital saat ini, sebutannya mulai berbeda. Sebelumnya memasuki era digital, objek dakwah harus bertemu secara langsung dengan pendakwah untuk bisa belajar agama. Namun dengan berkembangnya teknologi komunikasi, mitra dakwah hanya perlu melihat di konten Youtube tanpa perlu bertemu langsung dengan pendakwah. Dakwah di Youtube juga memberikan kemudahan dalam mendapatkan jawaban atas persoalan keagamaan (Alam, 2019). Mitra dakwah di media sosial dikenal juga sebagai netizen, dimana mereka yang aktif dalam media online. Selain itu dalam Youtube juga terdapat fitur trending tab, dimana dapat menjadi peluang untuk lebih mengenalkan video dakwah. Dalam Youtube juga terdapat interaksi antara pendakwah dengan objek dakwah berlangsung di kolom komentar, ataupun melalui video streaming di siarang langsung. Dari sini seorang pendakwah dapat mempelajari karakteristik dari objek dakwahyaitu netizen. Netizen atau warga internet merupakan kelompok individu yang melakukan aktivitas di dunia maya. Demografi pemakai internet saat ini didominasi oleh kalangan menengah keatas dengan tingkat intelektualitas yang berkelas (Alam, 2019). Mitra dakwah di Youtube dinilai beragam, karena siapapun dengan latar belakang apapun dapat mengakses konten tersebut. Dilihat dari pengguna internet banyak didominasi oleh generasi berusia 15-19 tahun dengan presentase 91\%, sedangkan generasi dengan usia 20-24 tahun berjumlah 88,5\% (Wijaya, 2015). Netizen sebagai mitra dakwah juga terbagi dalam dua kelompok, yakni mukmin dan kafir, sebagaimana ciri-cirinya banyak disebutkan dalam alQur'an. sedangkan dari kualitas keimanan Rosulullah Saw menyebutkan dalam hadistnya empat tipologi mitra dakwa, yaitu:

"Hati (manusia) itu terbagi atas empat, yaitu hati tidak ternodai seperti lampu yang bersinar; hati yang tertutup karena terikat oleh tutupnya; hati yang terbalik dan hati yang tertempa. Adapun hati yang tidak ternodai adalah hati orang yang beriman. Lampu hatinya adalah merupakan cahayanya. Adapun hati yang tertutup adalah hati yang kafir. Hati yang terbalik adalah hati orang yang munafik. Ia mengetahui kebenaran, tetapi ia mengingkarinya. Adapun hati orang yang tertempa ialah hati yang didalamnya ada keimanan dan kemunafikan. Perumpamaan iman dalam hati laksana sayuran yang ditumbuhkan oleh air yang segar. Adapun kemunafikan dalam hati laksana luka yang diperparah oleh nanah dan darah. Di antara keduanya (iman dan munafik) yang dominan atas yang lain berarti yang mengalahkannya" (Ahmad bin Hanbal, t.t, III, 17) (Aziz, 2017).

Netizen sebagai mitra dakwah juga terbagi berdasarakan karakter diatas, lebih lagi dakwah di media sosial Youtube yang dapat diakses oleh siapapun, baik dari kelompok muslim 
maupun non muslim. Netizen disini sebagai mitra dakwah di media sosial Youtube juga bagian dari kelompok masyarakat.

Mitra dakwah meliputi masyarakat dapat dilihat dari berbagai segi, yakni: a) segi sosiologis merupakan masyarakat terasing, pedesaan, kota besar, dan kecil, serta masyarakat marginal di kota besar; b) segi struktur kelembagaan berupa masyarakat pemerintahan dan keluarga; c) segi sosio kultur meliputi golongan priyayi, abangan, dan santri, klasifikasi ini terdapat pada masyarakat jawa; d) dari segi usia meliputi golongan anak-anak, remaja, dan orang tua; e) segi masyarakat yang berhubungan dengan golongan profesi atau pekerjaan; f) dari segi jenis kelamin, dan; g) dari segi golongan khusus seperti tuna wisma, tuna susila, dan narapidana ( dalam Marwantika, 2019).

Netizen sebagai mitra dakwah, tentunya mencakup semua lapisan masyarat dari berbagai segi Keberagaman latar belakang netizen di media sosial Youtube menjadi tantangan tersendiri bagi seorang pendakwah untuk dapat mencapai tujuan dakwah. Sebelum seorang da'i masuk ke lapangan tentunya diperlukan persiapan terlebih dahulu, oleh karena itu pentingnya sebuah perencanaan dakwah agar tujuan dakwah tercapai.

\section{Posisi Psikologi Massa dalam Perencaan Dakwah di Youtube}

Dakwah yang merupakan bagian dari proses komunikasi, dalam pelaksanaannya menggunakan dua jenis komunikasi, yakni: komunikasi antara Allah dengan umat-Nya atau sebaliknya, dan komunikasi antar umat manusia itu sendiri (Suhandang, 2013). Dalam komunikasi sendiri terdapat suatu perencanaan sebagai arahan untuk dapat mencapai tujuan komunikasi. Dakwah sebagai proses komunikasi memasukkan perencaan sebagai unsur dakwah, hal ini ditujukan agar pendakwah mendapat arahan sebelum memasuki lapangan dan agar dakwahnya tersusun dengan rapi. Perencanaan dakwah sendiri merupakan proses pemikiran dan pengambilan keputusan yang matang dan sistematis, mengenai tindakan, program, media dakwah, personel da'i, sasaran dakwah, dan materi dakwah yang akan dilakukan pada masa yang akan datang dalam rangka penyelenggaraan dakwah (Alfian, 2018). Perencanaan dakwah yang matang dapat mempengaruhi tercapainya tujuan dakwah.

Terdapat beberapa tahapan yang digunakan dalam perencanaan dakwah, yakni:

1) Menetapkan tujuan dakwah. Tujuan ini dimulai dengan keputusan dari keinginan atau kebutuhan da'i.

2) Merumuskan keadaan saat ini. Hal ini berkaitan dengan identifikasi kondisi yang saat ini dihadapi oleh masyarakat sebagai mitra dakwah. Pada tahap ini diperlukannya informasi mengenai khalayak, bisa menggunakan analisis khalayak.

3) Mengidentifikasi segala kemudahan dan hambatan, dengan cara mengukur kemampun pendakwah, serta tantangan yang dapat menghambat tercapainya tujuan dakwah.

Mengembangkan rencana dakwah, bisa berupa pengembangan berbagai alternative untuk mencapai tujuan dakwah, penilaian dan evaluasi penilaian, dan pemilihan alternatif yang lain dari alternatif yang ada. (Alfian, 2018)

Dari tahapan perencanaan dakwah diatas, dapat juga digunakan untuk merencanakan dakwah di Youtube. Pada tahap pertama yakni tujuan dakwah, tidak lain sellu diarahkan untuk dpat mempengaruhi tiga aspek perubahan dari mitra dakwah, berikut: a) perubahan pada aspek pengetahuan; b) aspek sikap, dan; c) aspek perilaku (Fabriar, 2019). identifikasi masalah, dilihat saat ini dimana masyarakat mulai banyak beralih ke media sosial sebagai sarana untuk membagi dan mendapatkan informasi. Media sosial memberikan kebebasan pada setiap individu untuk menyampaikan pendapatnya, tidak jarang pendapat mereka terkesan kasar. Mitra dakwah di media sosial dikenal sebagai netizen.

Dari sini posisi psikologi massa dalam perencanaan dakwah di Youtube terdapat pada tahapan kedua, yakni melihat kondisi mitra dakwah. Pada tahap ini untuk melihat karakteristik mitra dakwah, dan untuk menentukan metode dakwah sesuai dengan realitas khalayak. Dalam 
analisis khalayak terdapat tiga aspek yang bisa digunakan untuk melihat keadaan khalayak sebagai mitra dahwah, yakni: a) segi demografi; b) segi geografis, dan; c) segi psikografis. Posisi psikologi massa dalam kajian perencanaan dakwah di youtube, terletak pada psikologi massa. Psikologi massa memiliki peran besar dalam melihat perilaku netizen sebagai kelompok massa yang ada di media sosial. Psikologi massa merupakan cabang ilmu psikologi yang lahir pada abad ke-19, diperkenalkan oleh Gustave le bon. Psikologi massa merupakan berasal dari dua kata, yakni psikologi dan massa. Menurut Zimmer Psikologi didefinisikan sebagai studi ilmiah tentang proses mental dan perilaku manusia (Daulay). Sedangkan untuk massa sendiri merupakan kumpulan individu, dalam kumpulan tersebut tidak adanya interaksi serta tidak ada struktur dan pada umumnya massa berjumlah banyak orang dan berlangsung lama (Wahyono, 2016). Jadi psikologi massa menitikberatkan pada studi ilmiah terhadap perilaku dari kelompok individu yang berhubungan dengan perilaku yang dilakukan secara bersama oleh sekelompok massa yang bisa dikatakan sebagai perilaku kolektif. Sebagai kelompok massa tentu memiliki sifat-sifat sebagai berikut: 1) implusif, mudah memberikan respon terhadap rangsangan atau stimulus yang diterimannya; 2) mudah sekali tersinggung; 3) sugestibel, mudah menerima sugesti dari luar; 4) tidak rasional; 5) adanya social facilitation, adanya suatu penguatan aktifitas yang disebabkan oleh aktifitas individu lain (Tim Pokja Lemdiklat Polri, 2018).

Dalam hal ini massa sendiri memiliki beberapa jenis yang dilihat dari bentuknya, aktivitasnya, jumlah orang di dalam massa, waktu terbentuknya massa, tingkat keyakinan anggota terhadap kelompoknya, dan penyebaran massanya. Dari bentuknya massa terbagi menjadi dua, yaitu: massa terorganisir, dan massa tidak terorganisir. Dilihat dari aktivitasnya terdiri dari massa pasif dan massa pasif. Jenis massa tersebut juga memiliki karakteristik yang berbeda-beda, sehingga membentuk sifat-sifat tersendiri. Sebagaimana seorang individu yang tergabung dalam massa, kemudian akan bertidak sesuatu, yang mana tindakan tersebut tidak akan dilakukan apabila ia tidak tergabung dalam massa. Dengan demikian massa memiliki kemampuan untuk melarutkan individu dalam jiwa massa (Tim Pokja Lemdiklat Polri, 2018).

Netizen di media sosial dalam berkepentingan untuk melihat dakwah, dilihat dari jumlah orang di dalam massa tersebut termasuk dalam massa besar. Dimana mereka memiliki jumlah anggota sangat besar yang terdiri dari individu-individu, baik yang terorganisir maupun tidak berkumpul karena adanya dorongan, perhatian dan kepentingan yang sama (Wahyono, 2016). Dari pandangan psikologi massa memiliki arti yang berbeda. Sebagaimana saat dalam keadaan tertentu kelompok manusia menunjukkan karakteristik baru yang sangat berbeda dari individu yang menyusunnya (Bon, 2009). Dengan ini terdapat cabang ilmu psikologi yang memfokuskan pada perilaku dan karakteristik kelompok-kelompok individu yakni psikologi massa.

Berdasarkan pada tulisan Chaplin, psikologi massa merupakan cabang ilmu psikologi yang secara khusus mempelajari tentang perilaku manusia dalam loosely organized group atau kelompok yang tidak terstruktur (Polri, 2018). Psikologi massa dapat dikatan sebagai cikal bakal lahirnya psikologi sosial. Psikologi masa itu dibentuk, dan bersifat sementara namun ditentukan oleh karakteristik yang umum. Dalam karakteristik umum itu sendiri terdapat karakteristik khusus yang bervariasi berdasarkan pada massa yang membentuknya (Bon, 2009). Dalam suatu massa atau disebut sebagai kerumunan terdapat individu-individu yang berinteraksi, dimana masing-masing individu memiliki perilaku sosial yang berbeda-beda. Dalam memahami psikologi massa tentu harus lebih memahami tentang karakteristik dari massa itu sendiri. Disamping itu menurut Gustave Le Bon di dalam massa terdapat hukum kesatuan mental atau law of mental unity, dimana dalam massa adanya kesatuan pikiran, dan kesatuan jiwa (Tim Pokja Lemdiklat Polri, 2018). Oleh karena itu psikologi massa tidak melihat pada perilaku individu, namun lebih pada sekumpulan individu, dimana mental individu sudah menyatu dengan massa. Psikologi massa sangat berhubungan dengan perilaku yang dilakukan bersama-sama dalam sekelompok massa. Dengan ini akan membentuk perilaku kolektif, yang 
mana sekelompok individu yang ingin melakukan perubahan sosial dalam kelompoknya, institusinya atau dalam masyarakatnya (Wahyono, 2016). Netizen sebagi mitra dakwah memiliki latar belakang yang beragam, sehingga sasaran dakwah di media sosial Youtube disasarkan pada semua golongan masyarakat.

Sebagimana dalam psikologi massa yang mengkaji perilaku dan karakter manusia dalam kelompok massa, serta mental individu akan melebur dengan massa, sehingga mewujudkan perilaku kolektif. Youtube sebagai sarana bagi khalayah untuk berkumpul dan berinteraksi dengan kepentingan yang berbeda-beda. Sebagaimana pada psikologi massa tindakan atau kegiatan individu dapat melebur dalam perilaku kolektif atau tindakan massa. Fitur tab trending dalam Youtube dimaksud untuk menampilkan video yang dianggap menarik oleh banyak penonton, dan video yang sedang tren pada saat itu (Indonesia, 2019). Dalam dakwah di media sosial Youtube, dimana terdapat fitur trending tab akan mempengaruhi mental individu untuk ikut menyaksikan video yang sedang banyak ditonton oleh netizen lain. disisi lain pendakwah juga harus menyusun rencana materi dakwah yang menarik, dikarenakan dalam tab trending memiliki syarat-syarat tentu.

Berdakwah di Youtube juga perlu dilakukan dengan hikmah, agar pesan-pesan keaggamaan dapat diterima dengan baik oleh netizen. Dalam al-Qur'an sendiri menyebutkan dalam surat an Nahl ayat 125 , yang artinya:

"Serulah manusia kepada jalan Tuhan-mu dengan hikmah dan pelajaran yang baik dan bantahlah mereja dengan cara yang baik. Sesungguhnya Tuhanmu Dialah yang lebih mengetahui tentang siapa yang tersesat dari jalan-Nya dan Dialah yang lebih mengetahui orang-orang yang mendapat petunjuk".

Pemakaian bahasa yang baik dan tutur kata yang dilakukan pendakwah saat menyampaikan material dakwah, akan mendapatkan respon positif dari mitra dakwah. Respon mitra dakwah dalam berdakwah di Youtube dapat diketahui melalui banyaknya komentar positif, banyaknya like, dan subscriber. Dari ketiga itu akan membawa video dakwah masuk dalam tab trending, yang kemudian dapat mempengaruhi perilaku kolektif netizen untuk melihat video dakwah yang sedang tren.

\section{PENUTUP}

Kemajuan teknologi dan penggunaan internet, memunculkan media baru yang berbasis online, bahkan interaksi sosial saat ini bisa melalui internet. Perkembangan media menjadi peluang tersendiri untuk berdakwah, salah satunya melalui media sosial Youtube. Youtube menjadi salah satu media sosial yang banyak diakses oleh masyarakat Indonesia, dengan ini Youtube dapat sebagai media efektif untuk berdakwah. Dakwah sendiri merupakan suatu dorongan yang dilakukan untuk mengajak orang lain menerima ajaran agama dengan penuh kesadaran. Dalam dakwah terdapat beberapa unsur, seperti pendakwah (subjek dakwah), mad'u (mitra dakwah), materi, metode, media, dan tujuan, selain itu perencanaan juga dimasukkan dalam unsur dakwah. Sebagai seorang pendakwah yang menyampaikan pesan dakwah harus mampu memberikan rangsangan pada mitra dakwah sehingga mereka dapat berperilaku sebagaimana tujuan dakwah. Mitra dakwah di media sosial Youtube disebut netizen, dimana mereka memiliki latar belakang yang beragam, dan membentuk suatu kelompok.

Sebelum melakukan dakwah di Youtube, seorang pendakwah tentunya harus membuat suatu perencaan dakwah, sehingga dakwah dapat tersusun dengan rapi. Dari perencanaan yang matang akan memudahkan dalam mencapai tujuan dakwah. Psikologi menjadi salah satu hal terpenting dalam merencanakan dakwah, posisi psikologi dalam perencanaan dakwah terdapat pada analisis khalayak dari segi psikografis. Dari segi psikologi massa yang dapat meleburkan perilaku individu menjadi perilaku koletif, dapat membantu pendakwah untuk merencanakan dakwah di Youtube. Perilaku kolektif netizen dapat dilihat dari adanya tab trending di Youtube. Tab trending merupakan salah satu fitur di Youtube, dimana video yang paling 
banyak ditonton netizen, dan sedang tren pada saat itu. Dengan adanya ini pendakwah dapat mengemas materi dakwah, serta memperindah konten dakwah agar masuk dalam tab trending.

\section{DAFTAR PUSTAKA}

Vito, A. D. (2018). Pengaruh Efektivitas Youtube Terhadap Popularitas Tokoh Masyarakat. Biomass Chem Eng, 3(2).

Alam, L. (2019). Dakwah Dan Populisme Media: Idealisme Keberagamaan Netizen di Era Global. Al-I'lam: Jurnal Komunikasi Dan Penyiaran Islam, 2(2), 32. doi: 10.31764/jail.v2i1.1258

Alfian, A. (2018). Manajemen Perencanaan Dakwah. Al Imam: Jurnal Manajemen Dakwah, $71-77$.

Aziz, M. A. (2017). Ilmu Dakwah. Jakarta: Kencana.

Bon, G. L. (2009). The Crowd. New Zealand: The Floating Press.

Daulay, N. (2014). Pengantar Psikologi dan Pandangan Al-Qur'an Tentang Psikologi. JAKARTA: KENCANA.

Fabriar, S. R. (2019). Urgensi Psikologi Dalam Aktivitas Dakwah. An-Nida: Jurnal Komunikasi Islam, 11(2). doi: 10.34001/an.v11i2.1027

Indonesia, C. (2019, 05 01). Youtube Ungkap Alasan Video Masuk'Trending'. Retrieved 07 02, 2021, from CNNIndonesia.com: https://www.cnnindonesia.com/teknologi/20190430202737-185-390970/youtubeungkap-alasan-video-bisa-masuk-trending.

Marwantika, A. I. (2019). Potret dan Segmentasi Mad'u Dalam Perkembangan Media di Indonesia. Al-Adabiya: Jurnal Kebudayaan Dan Keagamaan, 14(01), 1-14. doi: 10.37680/adabiya.v14i01.100

Mustofa, H. (2011). Perilaku Manusia dalam Perspektif Psikologi Sosial. Administrasi Bisnis, 7 , 143-156.

Polri, T. P. (2018). Psikologi Massa dan Negosiasi. Jakarta: Lwmbaga Pendidikan dan Pelatihan Polri.

Putra, M. G. (2012). Pengantar Psikologi Sosial. surabaya : Pusat Penerbitan dan Percetakan Unair (AUP).

Suhandang, K. (2013). Ilmu Dakwah Perspektif Komunikasi. Bandung: PT Remaja Rosdakarya.

Sulaeman, A. R., Fazri, A., \& Fairus, F. (2020). Strategi Pemanfaatan Youtube Dalam Bidang Dakwah Oleh Ulama Aceh. Communication, 11(1), 81-93.

Wahyono, A. (2016). Psikologi Massa. Semarang, Jawa Tengah: Kementerian Pendidikan dan Kebudayaan.

Wijaya, I. S. (2015). Perencanaan Dan Strategi Komunikasi Dalam Kegiatan Pembangunan. Lentera, 17(1), 53-61. 